\title{
FOTO SEJARAH PADA MEDIA DIGITAL: PEWARNAAN DAN MEME BERKONTEN SEJARAH
}

\author{
Iman Zanatul Haeri
}

Guru Sejarah MA Pondok Pesantren Luhur Al-Tsaqafah, (Jakarta Selatan) Email: imanzanatulhaeri91@gmail.com

\begin{abstract}
Technological developments make it easier for historical reviewers to approach historical sources. But there is a trend in Indonesian digital society to change historical sources such as historical photos as information consumption. Along with the development of the times, analog photos turned into historical photos that were present in the millennial era appeared in two ways; first coloring photo history, the second "meme" set in historical photos. In order to track digital footage of this phenomenon, historical methodology and photo analysis of Roland Barthes are used to show the birth of historical photo coloring trends and memes in the digital world. The coloring of historical photos causes a change in time awareness of historical sources and memes on historical photographs cause a change and multiplication of meanings in digital photos as historical sources.
\end{abstract}

Keywords: Sumber sejarah, Pewarnaan, Meme, Foto Sejarah, Generasi Milenial.

\section{PENDAHULUAN}

Para peneliti sejarah Indonesia memiliki kesulitan untuk mendapatkan sumbersumber sejarah Indonesia, karena beberapa bahan sejarah tersebut berada di museum Belanda. Seiring perkembangan zaman dan masuknya era digital pada akhir abad ke20, koleksi sumber sejarah Indonesia yang ada di museum Belanda dapat diakses melalui perpustakaan digital yang diluncurkan oleh perpustakaan digital koleksi Koninklijk Instituut voor Taal-, Land-en Volkenkunde (KITLV) Universiteit Leiden. Bila mengacu pada Perpustakaan Nasional Belanda (Koninklijke Bibliotheek), upaya untuk melakukan pengarsipan digital terhadap koleksi museum dan seluruh perpustakaan di Belanda sudah dimulai sejak tahun 2000 (Rotenberg, 2000). Dengan demikian, para peneliti sejarah kini memiliki kemudahan-kemudahan untuk mengakses sumbersumber sejarah secara digital.

Salah satu sumber sejarah yang melimpah disajikan oleh museum tersebut adalah foto sejarah. Jumlah keseluruhan dokumentasi digital perpustakaan tersebut sebanyak 190.000 koleksi foto sejarah (KITLV Media). Jumlah tersebut masih separuh dari koleksi seluruh foto cetak yang dimiliki perpustakaan digital KITLV, yang mencapai 300.000 foto (Matanasi, 2016). Selain itu, foto sejarah juga tercatat memberi arti yang lebih kaya terhadap suatu peristiwa sejarah. Kajian sejarah menggunakan foto sejarah digital pernah dilakukan oleh Jean Gelman Taylor. Dalam kajiannya menelaah foto-foto sejarah Aceh koleksi museum digital KITLV (1874-1939), ia hanya 
melakukan kategorisasi (tema, lokasi, geografi dan lainnya) pada koleksi yang dikumpulkan secara digital (Nordholt \& dkk, 2008). Meskipun demikian, risiko menjadikan foto digital sebagai sumber sejarah harus disertai pengetahuan yang cukup baik tentang perubahan medium dan transformasi media pada foto digital.

Pada perkembangan selanjutnya, keberadaan foto sejarah digital bisa diakses oleh masyarakat awam, sehingga mereka memperlakukannya tidak sebatas sumber sejarah yang memiliki potensi menjadi bahan penelitian sejarah. Namun mereka memperlakukannya sebagai medium ekspresi dunia digital. Mereka adalah suatu generasi Indonesia yang aktif menggunakan media sosial, memiliki kemampuan untuk menggunakan perangkat digital, pelaku aktif gawai, dan memiliki karakter suatu generasi yang disebut generasi milenials (Ali, Hasanuddin \& Purwandi, Lilik, 2016). Kemampuan di bidang digital membuat siapa pun di era digital dapat mengakses sumber sejarah, seperti foto sejarah digital.

Mereka mengubah atau menambahkan "sesuatu" pada foto sejarah sehingga menimbulkan nuansa humor, disebut meme foto sejarah. Selain itu, perkembangan teknologi fotografi digital memunculkan suatu tren baru untuk mengubah warna foto sejarah hitam-putih (monokrom) menjadi foto sejarah berwarna. Teknik ini disebut Colourizing Photography. Kedua fenomena tersebut memiliki implikasi filosofis terhadap kedudukan foto sejarah sebagai sumber sejarah.

Sementara itu, penelitian sejarah cenderung mengarahkan kajiannya pada interpretasi teks, sedangkan sumber sejarah seperti peninggalan kebendaan diletakkan hanya sebagai penyambung teks yang terputus. Prasasti yang ditemukan di berbagai belahan nusantara, kegunaan utamanya dalam penelitian sejarah hanya sebagai penanda waktu sebuah peristiwa sejarah (uji karbon). Sedangkan interpretasi atas peristiwa sejarah itu sendiri lebih banyak digali dari teks yang terdapat pada prasasti tersebut. Roland Barthes menyebutnya sebagai pesan linguistik. Hal ini menandakan kedudukan teks yang lebih tinggi daripada ketampakan benda yang bisa menunjukkan suatu peristiwa lampau. Selain itu, kecenderungan tersebut menyebabkan literatur filsafat sejarah yang membahas tentang sumber sejarah hanya mengarahkan sebagian besar penjelasannya pada analisis teks (seperti hermeneutika). Adapun sumber lisan yang digunakan tetap diubah terlebih dahulu menjadi teks. Sedangkan foto sebagai sumber sejarah lebih banyak disinggung oleh bidang lain di luar sejarah.

\section{FOTO SEBAGAI ARTIFAK DIGITAL}

Meski demikian, bukan berarti tidak ada sama sekali pemikir sejarah yang menyinggung kedudukan penting foto sebagai sumber sejarah. March Bloch (18861944) pendiri jurnal sejarah Perancis Anales pada tahun 1929 menulis Sejarah Pertanian Abad Pertengahan. Bloch menyelidiki bukti-bukti dari nama lapangan, peta pemukiman, artefak teknis, dokumen tradisional hingga foto udara. Majalah Anales ini kemudian dikenal sebagai Mazhab anales atau sejarah total karena salah satu yang paling menonjol dari kemunculan mazhab ini adalah keputusannya untuk memperluas secara besar-besaran daftar sumber yang mendasari penelitian sejarah. Menurut Miriam Dobson \& Benjamin Zieman, penggunaan berbagai sumber sejarah 
secara luas dilakukan oleh mazhab Anales karena terdapat tantangan dari filologi yang sudah sejak awal mendasari domain keilmuannya pada interpretasi teks. Keputusan tersebut membuka peluang sejarawan modern dapat menggunakan sumber non-tekstual seperti film, kartun hingga foto sebagai sumber sejarah (Dobson, 2009; Angkersmith, 1987).

Kuntowijoyo dalam Pengantar Ilmu Sejarah mengemukakan bahwa foto sejarah masuk dalam bagian tahap awal dari penelitian sejarah, yaitu tahap pengumpulan sumber (heuristik). Pada tahap pengumpulan sumber sejarah, menurut bahannya, dapat dibagi dua: dokumen dan artifact (artefak). Artifact menurut Kuntowijiyo dapat berupa foto-foto, bangunan atau alat-alat. Ia menambahkan "foto dari setiap generasi akan menunjukkan perubahan sosial antar keluarga dan antargenerasi. Demikian juga data lain tentang perabot rumah, pakaian, kendaraan, klangenan, mungkin terungkap lewat foto" (Kuntowijoyo, 2001). Namun pengertian tersebut dimaksud bagi foto sejarah yang dalam bentuk fisiknya adalah kertas foto. Sedangkan foto digital, memiliki ruang yang cukup kontroversi bagi autentifikasi dan keabsahan sumber sejarah. Hal ini karena foto sejarah dalam bentuk kertas foto di satu sisi, dan foto digital di sisi lain, masingmasing memiliki bentuk dan media yang berbeda.

Menggunakan istilah fotografi, Louis Gottschalk bermaksud menunjukkan fenomena fotografi secara menyeluruh, tidak hanya "foto" sebagai hasil akhir. Perkembangan fotografi sebagai sumber sejarah pernah diulas olehnya untuk menunjukkan bahwa-tercapainya teknologi mikrofilm-dapat membantu sejarawan, tidak hanya dalam kedudukan foto dalam sumber sejarah. Lebih dari itu ia menyarankan perubahan medium dokumen-dokumen sejarah agar dimicrofilmkan. Atau dengan kata lain, ia menghendaki perkembangan reproduksi fotografis digunakan dalam proses penelitian sejarah. Ia menyarankan pencatatan sumbersumber sejarah direproduksi seperti fotostat dan mikrofilm agar membuat penelitian sejarah lebih efisien. Pada periode 1980-an, fotostat dan mikrofilm merupakan teknik baru dalam menyimpan foto sejarah yang memiliki kecepatan 10.000 reproduksi setiap menit (Gottschalk, 1986). Selain sebagai artefak fisik, foto bisa disimpan sebagai artefak digital. Perkembangan teknologi komputasi membuat foto sejarah bisa disimpan sebagai data digital.

Sebagai contoh, gagasan ruang dan waktu sebuah foto sejarah di dalam data digital mengalami distorsi. Data digital yang tampil dalam layar, tidak muncul dalam ukuran yang sebenarnya. Berbeda dengan artefak material yang menggunakan banyak ruang. Selain itu, objek fisik menghadapi persoalan seperti kerusakan, debu, kotor dan perubahan fisik lainnya akibat interaksi dengan cuaca. Berbeda dengan foto kertas, foto sejarah digital mengalami kondisi stabil dengan cara disalin menggunakan perangkat aplikasi digital (Harrison, 2015). Meski hal ini rentan akan perubahan bentuk, namun perjalanan suatu foto digital pada tiap 'memori komputer' tetap bisa dilacak keberadaannya.

Cara kerja artifak digital yang disalin secara terus menerus dan tersimpan dalam setiap memori perangkat computer sangat mirip dengan persebaran gen manusia. Hal ini dikemukakan oleh Richard Dawkins. Ia menjelaskan mengenai prinsip dasar teori evolusi Darwin, yakni sebuah proses ketika informasi disalin, lagi dan lagi, dengan beberapa variasi dan seleksi variasi lainnya, maka terjadilah proses evolusioner (Dawkins, 2018). Ia menganggap bahwa meme mirip dengan gen yang 
diturunkan dari orang tua kepada anaknya. Pencetus sosio-biologi E.O. Wilson menambahkan bahwa gen yang menjaga "budaya" tetap dalam sebuah ikatan. Dalam pandangan ini, meme akan menjadi budak dari gen, sebab otak sebagai pusat informasi akan berfungsi dengan baik apabila membantu gen berkembang biak (Blackmore, 2000).

Henry Plotkin keberatan dengan pengertian tersebut. Ia menyatakan bahwa orang-orang melakukan hal lebih dari sekedar imitasi. Ia keberatan bahwa budaya dan sejarah manusia hanya salinan-salinan variasi meme dari masa sebelumnya. Meme bukanlah seperti ide Plato yang terbang-bebas. Ia menegaskan, meme adalah memori spesifik tentang aktivitas dan artefak manusia (Blackmore, 2000). Meme diartikan sebagai berbagai informasi yang berbentuk artefak, yang bisa dilacak sebagai bagian dari salinan-salinan informasi dari masa sebelumnya.

Melalui pengertian tersebut, foto sejarah digital bisa masuk dalam kategori artefak digital sebab sifat utamanya yang merupakan salinan informasi spesifik tentang aktivitas manusia. Namun, bagaimana foto sejarah digital beroperasi didunia internet menimbulkan berbagai pertanyaan dan fenomena. Persoalan yang dimaksud adalah bagaimana kedudukan foto sejarah digital sebagai sumber sejarah dan bagaimana dinamika foto sejarah digital di dunia internet.

Dapat dirumuskan, pertama, bagaimana perkembangan foto digital sebagai sumber sejarah? Kedua, bagaimana risiko filosofis dan metodologis dari fenomena pewarnaan foto sejarah dan meme foto sejarah? Kedua pertanyaan tersebut akan dianalisis dengan metodologi sejarah, yaitu dengan cara mengumpulkan bahan-bahan sejarah guna menunjukkan bagaimana perubahan foto cetak sampai foto digital, hingga teknik mengubah foto digital. Kemudian untuk menganalisis dampak filosofis dari perubahan foto sejarah yang terjadi dalam fenomena pewarnaan foto sejarah dan meme foto sejarah, menggunakan analisis pesan fotografis Roland Barthes.

\section{FOTOGRAFI ANALOG DAN DIGITAL}

Istilah fotografi berasal bahasa Yunani, Photos dan Graphos, yang memiliki makna 'menggambar cahaya'. Pada pengertian selanjutnya, fotografi didefinisikan sebagai gambar yang cukup stabil, yang diakibatkan oleh efek cahaya pada zat kimia. Stabilitas menjadi kunci dari pengertian fotografi. Tanpa stabilitas, maka gambar yang dihasilkan menjadi rapuh dan retak. Istilah fotografi pertama kali digunakan oleh Antonie Hercules Remuald Florence pada tahun 1833. Istilah ini digunakan kembali oleh John Herschel pada tahun 1839 untuk menjelaskan proses dan produk fotografi. Sedangkan gambar pertama fotografi tercatat lebih awal, dibuat oleh Thomas Wedgwood dan dikupas dalam sebuah jurnal tahun 1802.

Namun, peletak dasar fotografi modern atau metode kamar gelap, Albeit Almuzlim, yang lebih dikenal sebagai camera obscura sudah ditemukan dalam kitab Ibn Al-Haytham berjudul Al-Manazir atau Book of Optics (De Aspectibus). Pada tahun 2015 dalam perayaan The International Year of Light, Al-Hassan Ibn Al-Haytham ditetapkan sebagai bapak optik modern (Iskandar, 2014). Buku ini menjadi rujukan karena Ibn Al-Haytham melakukan telaah kritis terhadap karya pemikir-pemikir Yunani seperti Ptolemy dan Euclid yang mengatakan bahwa manusia melihat benda melalui pancaran cahaya yang keluar dari matanya. 
Prinsip kamera obscura kembali dipakai oleh Josep Nicephore Niepce bersama Louis Jacques Mande Degurerre (1826). Setelah kematian Niepce tahun 1833, temuan Deguerre yang menggunakan teknik gambar tersembunyi dan penggunaan perak yang dikombinasi dengan yodium menjadi basis utama perkembangan kamera pada abad ke-19. Penemuan penting selanjutnya dilakukan oleh William Henry Fox Talbot tahun 1834. Ia berhasil melakukan stabilisasi atas kertas foto negatif dan positif, yang disebut sebagai gambar fotogenik (Peres, 2012). Kemudian di tahun 1888, ilmuwan dari Amerika, George Eastman memasarkan kamera tangan dengan merek 'Kodak' dan pada tahun 1891 ia memasarkan gulungan film dengan bahan dasar seluloid.

Tahun 1900 Easman memunculkan Kodak Brownie yang memungkinkan setiap orang dapat memiliki kamera secara murah dan dapat memotret dengan sangat mudah. Kodak kembali memperkenalkan film berwarna pada tahun 1935, lalu foto langsung jadi Polaroid diluncurkan pada tahun 1947, dan kamera digital baru dipasarkan pada tahun 1996. Penemuan ini membuat para pembuat kamera dapat memberi warna pada foto yang dicetak. Pewarnaan dalam foto merupakan revolusi besar dalam mencetak realitas secara sempurna. Ketika fotografi ditemukan pertama kali (sekitar 150 tahun yang lalu), seniman Paul Delaroche mengklaim "sejak hari ini, lukisan telah mati" (Mitchell, 1998).

Setiap foto memiliki pesan. Pada kajiannya tahun 1961, Barthes sudah mengupas fenomena foto yang berisi tulisan. Melalui keterbatasan teknologi pada era tersebut, foto yang di dalamnya berisi tulisan dimasukkan pada kategori foto berita. Lebih tepatnya foto yang dimuat dalam surat kabar cetak. Barthes mengupas proses terciptanya foto berisi tulisan dari pemancar pesan (pers yang bekerja di surat kabar) dan penerima pesan (publik pembaca). Bagi Barthes nama atau tulisan pada surat kabar yang berada pada sekitar foto berfungsi mengkoridor proses baca-tafsir terhadap pesan (Barthes, 2010). Ia menambahkan bahwa pada teks, substansi pesan dibangun oleh kata-kata, sedangkan pada foto substansi pesan dibangun oleh garis, tekstur, dan warna. Ia menyebutnya sebagai analisis struktural pesan fotografis.

Scene foto (peristiwa, aktivitas dan pemandangan) pada awalnya dianggap sebagai tiruan realitas. Sebab proses pembuatan foto hanya memindahkan realitas dan sama sekali tidak mencincang realitas terlebih dahulu menjadi unit-unit kecil. Barthes menyebutnya sebagai imaji fotografis yang didefinisikan sebagai analogon (turunan, salinan, dan kopian) yang sempurna dari realitas. Keistimewaan ini membuat foto bisa disebut sebagai pesan tanpa kode. Keistimewaan ini malah membawa foto pada konsekuensi berkelanjutan atau kontinu, karena dengan demikian foto menjadi gambaran realitas yang polos atau telanjang sehingga membuka peluang lahirnya lapis makna selanjutnya, yakni ketika munculnya pesan suplementer yang disebut gaya dalam reproduksi atau makna kedua (penanda) dan pertandanya (bersifat estetis atau ideologis) yang merupakan pendirian (budaya) tertentu dari masyarakat penerima pesan. Singkatnya, foto (seni imitatif) mengandung dua pesan. Pertama pesan denotatif atau analogon itu sendiri. Kedua, pesan konotatif yang merupakan pandangan masyarakat penerima pesan.

Pada tahap konotatif dibedakan menjadi dua tahap, tahap pertama: efek tiruan, sikap atau pose dan objek, dan tahap kedua; fotogenia, estetisisme dan sintaksis (Barthes, 2010). Perkembangan zaman membuat mudah kiranya menduga bahwa analisis Barthes atas foto mungkin saja tidak relevan untuk foto digital. Terdapat dua 
pandangan dalam analisis ini. Pertama, analisis Barthes bisa saja tidak relevan karena ruang digital menghadirkan "pemain baru" dalam industri makna. Iklan di era pradigital merupakan basis suprastruktur dari industri bersangkutan dan memancarkan sekian makna beragam yang kemudian berakhir pada himbauan membeli produk tersebut. Sedangkan di era digital, iklan mengalami kejutan "ongkos" besar, sebab di dunia tersebut memiliki aturan main sendiri sehingga makna bisa tertambat di dalamnya. Sebab iklan di dunia digital lebih interaktif.

Pandangan kedua menyatakan analisis Barthes masih sangat relevan, sebab ia mengarahkan kajiannya pada industri massa. Alasan utamanya bahwa industri belum mati. Alasan selanjutnya keanekaragaman produk budaya massa tetap berpangku pada keseragaman produksi. Selain itu, industri massa tidak berubah, ia hanya berganti dimensi. Artinya investasi terhadap pusat kebudayaan massa hanya dialihkan ke dunia digital, sehingga persoalan-persoalan yang muncul dari industri digital tidak mengubah prinsip dari analisis Barthes tentang budaya, dalam hal ini foto. Pandangan kedua ini tetap dipertahankan penulis.

Meski seperti itu, pengaruh politik dan perkembangan teknologi membuka kemungkinan-kemungkinan baru direkayasanya sebuah foto cetak. Sesuai perkembangan zaman, masuknya era internet membuka peluang saling terkoneksinya hubungan manusia dan informasi. Hal ini membuat foto digital tidak hanya disimpan secara personal computer (PC), namun dapat disebar ke berbagai belahan dunia melalui jejaring internet. Seperti foto analog, foto digital juga memiliki potensi direkayasa dalam arti foto sejarah digital memiliki kemungkinan diubah pola garis dan warnanya oleh kepentingan-kepentingan tertentu. Hal ini membuat sejawan harus lebih terbuka atas perkembangan teknologi untuk dapat melakukan proses heuristik maupun verifikasi yang ketat, agar foto-foto rekayasa yang dimaksud tidak menjadi bahan dari kajiannya. Sebab hal itu akan mendistorsi interpretasi yang akan diajukan atas sumber-sumber sejarah yang telah dikumpulkan. Meskipun demikian, setiap foto digital memiliki riwayat perjalanan atau jejak digital yang tidak bisa hilang.

\section{FOTO DIGITAL FORENSIK}

Kemudahan berinteraksi (berbagi informasi) dengan peralatan digital telah menumbuhkan ketergantungan terhadap peralatan digital. Sebagaimana alat-alat yang berhasil diciptakan manusia, peralatan digital digunakan untuk mengolah data digital. Aktivitas tersebut meninggalkan jejak digital. Secara khusus Andri Puspo Heriyanto menunjukkan bagaimana mobile phone (serta jaringan GSM) juga tetap meninggalkan jejak digital dalam setiap aktivitasnya (Heriyanto, 2016). Tahun 1976 di Amerika Serikat, kesadaran akan potensi kejahatan yang tinggi di dunia digital menyebabkan munculnya hukum yang mengatur hal tersebut. Pertama, US Federal Rule of Evidence (1976). Kedua, the Electronic Communication Privacy Act (1986). Ketiga, the Computer Security Act (1987). Keempat, Economic Espionage Act (1996). Kecenderungan keamanan di dunia digital memang didorong oleh kebutuhan untuk melindungi data digital sebagai hak individu. Oleh sebab itu, upaya untuk mendorong investigasi terhadap bukti digital lebih didorong oleh bidang hukum, sebelum sejarawan mulai menyadari potensi tersebut (National Institute of Justice, 2008). Kebutuhan akan investigasi atas kejahatan di bidang digital, memerlukan suatu 
metode yang dapat mengambil bukti dari aktivitas melanggar hukum di dunia digital. Saat itu bidang forensik yang biasanya melakukan analisis terhadap bukti-bukti fisik kejahatan, kini memperluas kemampuannya dengan membuka cabang penyelidikan criminal yang disebut forensik digital. Istilah ini kadang disebut komputer forensik. Proses forensik digital melalui tahapan prosedural, yaitu collecting (pengumpulan), examination (pengujian), analysis (analisis), dan reporting (laporan). Keempat tahap ini hampir mirip dengan metodologi sejarah.

Meski sejarawan tidak dituntut untuk memiliki kemampuan yang sama dengan para ahli digital forensik, namun sejarawan bisa meminta bantuan para ahli digital forensik untuk membantunya dalam membentuk "fakta digital". Urutannya seperti ini: digital forensik melakukan tahap-tahap analisisnya, kemudian data yang sudah terkumpul digunakan sejarawan untuk mengubah 'data digital' menjadi fakta sejarah digital. Data digital dapat berupa file yang sederhana hingga file yang hanya bisa dibuka oleh aplikasi tertentu. Sebagai contoh, data digital berupa foto, bisa dibuka dalam format file bernama TIFF, GIF, JPEG, PNG, dan lainnya.

Cara lainnya-yang tidak melibatkan digital forensik-merupakan cara yang biasa dilakukan sejarawan terhadap analisis keaslian dokumen sejarah. Cara ini juga dipakai dalam dunia jurnalistik. Seperti penelusuran penulis, pemosting, integritas situs web asal 'data digital' tersebut, hingga pencarian yang mengutamakan kecermatan dan ketelitian sumber 'data digital'. Google bahkan sudah memiliki fitur pencarian asal sebuah gambar yang ditemukan dalam "pencarian google". Beberapa situs web bahkan menyediakan fitur untuk melacak asal suatu foto atau gambar di internet.

Perkembangan teknologi dari analog hingga digital; dokumentasi sejarah "naskah kertas" berubah menjadi mikrofilm kemudian dapat disimpan pada memori digital dan perubahan gambaran realitas; dari lukisan, foto monokrom-berwarna hingga foto digital telah mengubah pekerjaan-pekerjaan tradisional sejarawan maupun fotografer. Umumnya diketahui hanya sejarawan yang memiliki akses dan kemampuan mencapai sumber-sumber sejarah. Sama seperti fotografer yang ahli menggunakan kamera hingga tahap percetakan akhir. Setelah teknologi berkembang, dunia digital telah memperluas akses sumber sejarah berbentuk foto sejarah digital kepada banyak kalangan, sehingga para ahli dan pengguna dunia digital memiliki kemampuan untuk mengakses bahkan melakukan perubahan-perubahan fundamental pada "foto sejarah".

\section{MILENIALS}

Munculnya istilah millennial masih perlu diuji dan diteliti lebih jauh dalam konteks Indonesia. Istilah ini muncul di Amerika Serikat ketika menggambarkan perbedaan generasi penduduk mereka. Secara umum mereka mempercayai setiap generasi memiliki karakternya tersendiri. Labelisasi generasi tersebut bertitik tumpu pada peristiwa sejarah; Perang Dunia Kedua (PD II). Pembabakan generasi ini dimulai: silent generation yang mengacu pada generasi di Amerika Serikat yang merasakan PD II (sampai dengan 1946). Generasi selanjutnya, baby boomers atau ledakan kelahiran bayi yang lahir pasca PD II antara tahun 1946-1964. Setelah itu generasi X 1965-1984, lalu generasi Y kemudian generasi millennial. Penelitian 
Harvard Center (Generasi Y) dan tulisan yang memopulerkan kata millennials (Howe \& Strauss, 2000) memiliki kontradiksi waktu; generasi Y 1970 sampai 2000 sedangkan generasi millennial 1982 sampai 2004 (The Atlantic.com, 25 Maret 2014). Seorang professor Psikologi Jean Twenge meragukan ketepatan penyebutan generasi millennials dengan mengatakan "generations labels don't always reflect reality... often, they reflect the hopes of what people want a generation to be" (Horovitz, 2012).

Maka untuk menandai era digital, millennial di sini diartikan sebagai sebuah era, bukan sebuah generasi (manusia). Fenomena digital yang ingin ditandai adalah kemampuan memakai media sosial, aplikasi photo editing dan peselancar internetyang nantinya akan mempengaruhi foto digital sebagai sumber sejarah. Millennials di sini diartikan orang-orang yang hidup ketika wacana "millennial" begitu populer dalam bidang sejarah, ekonomi, budaya, antropologi, hingga ilmu-ilmu sosial. Bila milenials sebagai suatu generasi masih perlu dipertanyakan, namun wacana millennial yang memenuhi arus utama informasi tentang proyeksi masa depan suatu generasi yang dikaji keilmuan-keilmuan tersebut adalah fakta yang tidak bisa dibantah. Pergeseran penggunaan kata ini dilakukan agar tidak mengalami dislokasi istilah yang akan mempengaruhi analisis kedudukan foto sejarah di era millennials. Demi mengatasi persoalan tersebut, millennial cukup diartikan sebagai sebuah era yang berasal dari kata "milenium" yang dimulai sejak tahun 2000, dan di saat yang sama, dunia digital dan internet sudah tersebar ke berbagai belahan dunia termasuk Indonesia.

Tentu tidak dapat diabaikan juga penelitian yang sudah dilakukan dengan istilah millennials di Indonesia. Secara berurutan, Alvara Research Center melakukan penelitian tentang milenial Indonesia tahun 2016 dan tahun 2017. Penelitian tahun 2016 berjudul Indonesia 2020: The Urban Middle-Class Millennials menyimpulkan bahwa wajah Indonesia di tahun 2020 dengan kode C3, yaitu Creative, Connected, dan Confidence (Ali \& Purwandi, The Urban Middle-Class Millennials, 2016). Penelitian tahun 2017 berjudul The Urban Middle-Class Milenials Indonesia: Financial and Online Behavior menunjukkan bahwa penggunaan smartphone mencapai 99,1\% (Ali \& Purwandi, 2017). Penelitian ini sekurang-kurangnya menunjukkan aktivitas pengguna smartphone yang di dalamnya memiliki kemampuan menyimpan bahkan mengubah foto sejarah.

\section{PEWARNAAN FOTO SEJARAH}

Salah satu artefak atau sisa aktivitas kehidupan manusia adalah foto. Seperti yang sudah disebutkan, guna melacak jejak-jejak aktivitas manusia di masa lalu, maka diperlukan sebuah cara untuk mengumpulkan artefak (lihat penjelasan Kuntowijoyo sebelumnya) manusia. Langkah selanjutnya yang sangat rentan terhadap kesalahan tafsir adalah tahap interpretasi dari temuan artefak tersebut. Maka dari keterbatasan yang dimilikinya, metodologi sejarah perlu menggunakan ilmu-ilmu lain agar membantu menjelaskan artefak tersebut. Terlebih, keberadaan 'dunia digital' mengharuskan sejarawan mampu mengembangkan kaidah-kaidah tertentu guna menjawab kedudukan fakta sejarah di hadapan fenomena digital.

Artefak manusia yang mampu meniru gambaran realitas dan telah menjadi puncak imitasi, tiruan atau analog yang sangat sempurna adalah kemunculan foto. 
Namun metodologi sejarah dan pengalamannya berhadapan dengan sumber sejarah memiliki kemungkinan tergelincir oleh salah tafsir karena tidak memiliki pengetahuan yang memadai tentang bagaimana foto beroperasi dalam realitas. Kajian tentang foto merupakan bidang di luar sejarah tradisional. Pada tahun 1960an, ketika kebudayaan masa berkembang, muncul sebuah diskursus "semiotika" yang mampu membongkar lapisan makna dari foto dan motif-motif ideologis di dalamnya. Meski secara umum Roland Barthes menolak menyebut semiotika sebagai ilmu, namun semiotika cukup berhasil dalam menjelaskan bagaimana foto beroperasi seperti sudah diterangkan sebelumnya (Barthes, Petualangan Semiologi, 2007).

Seperti sudah disampaikan, perkembangan teknologi digital memungkinkan foto sejarah dapat diakses oleh berbagai kalangan di luar sejarawan. Perbedaan antara foto analog dan digital secara fundamental bagi kaidah ilmu sejarah adalah dalam tahap awal "efek tiruan". Foto digital sangat rentan diubah. Ditambah, alat untuk mengubah foto digital bisa diakses oleh banyak kalangan. Pada awalnya kemampuan mengubah foto digital dimiliki oleh kalangan tertentu yang berkepentingan dalam dunia fotografi. Kemudian, alat untuk mengubah foto secara digital terdapat di dalam Personal Computer (PC). Perangkat lunak ini berbentuk aplikasi, seperti Paint dan Microfost Office Picture Manager yang menjadi bagian dari fitur Windows. Kemudian muncul berbagai perusahaan penyedia perangkat lunak yang berkaitan dengan mengedit foto, seperti perusahaan Adobe yang menciptakan perangkat lunak Photoshop. Perkembangan perangkat lunak penyedia alat mengedit foto semakin beragam, namun itu tidak menjadi fokus kajian ini.

Fenomena editing foto muncul sekitar tahun 1990an yang dikenal sebagai "revolusi fotografi". Pada awalnya, di tahun 1987 Thomas Knoll menulis sebuah program display. Namun kemudian menjadi program penyunting gambar secara penuh menjadi photoshop. Program ini segera disambut oleh direktur seni Adobe, Russel Brown. Maka lahir Photoshop 1.0 pada tahun 1990 (Yulistianti, 2008; Barksdale, 2012). Photoshop menjadi penanda lahirnya revolusi fotografi karena memiliki alat untuk mengubah warna seperti RGB Color Mode, Lab Color Mode, CMYK Color Mode, Grayscale, Bitmap, dan Duotone. Pengembangan tersebut menciptakan seni pengolah gambar (photo retouching) dan mengubah cara kerja yang hanya dapat diciptakan oleh fotografer professional selama berhari-hari, kini dapat dikerjakan seniman amatir dalam hitungan jam.

Pada perkembangan lanjutan, revolusi seluler menyebabkan terciptanya telepon-telepon pintar berbasiskan teknologi yang setara dengan PC. Dengan demikian, alat untuk mengedit foto digital sudah dimiliki oleh smartphone. Aplikasi mengedit foto digital kemudian menjadi sebuah aplikasi "recehan" yang dibuat agar mudah digunakan pengguna awam. Fenomena 'kamera yang dimiliki semua orang' dan proses 'mengedit foto' yang bisa dilakukan oleh semua orang pemilik smartphone-belum terdengar kalangan fotografer analog mendeklarasikan "matinya" pekerjaan mereka secara tradisional seperti ungkapan pelukis 150 tahun silam.

Berarti kini masyarakat berbagai kalangan memiliki alat bahkan kemampuan untuk mengubah foto digital. Ditambah sampai tahun 2015 pengguna smartphone di Indonesia sebesar 55,4\%, tahun 2016 meningkat menjadi 65,2\%, dan diperkirakan hingga tahun 2019 mencapai 92,0\% penduduk Indonesia menggunakan smartphone (eMarketer, 2015). Pada perkembangan selanjutnya, hampir seluruh media sosial 
melengkapi fitur mereka dengan mengedit foto (Instagram, Facebook, Path, dan lainnya). Seperti mengubah gradasi warna, mengubah garis, menambahkan kata-kata, hingga bisa menghilangkan sekedar jerawat dalam foto digital. Selain meme foto sejarah, perkembangan mengedit foto membuat para seniman digital menciptakan beragam kreasi terhadap foto sejarah, yakni mengubah tekstur, warna, dan garis foto sejarah. Salah satu kemampuan mengedit foto sejarah dikenal dengan istilah Historic Photos in Color, Colorized Historical Photos, dan Colorized Black \& White Photos from History. Ketiga istilah ini disebut penulis sebagai proses pewarnaan foto sejarah monokrom. Kemudian disederhanakan menjadi 'pewarnaan foto sejarah'.

Pada tahun 2011, Sanna Dullaway - seorang seniman digital-memasang foto bersejarah di sebuah situs web hiburan reddit.com. Berbeda dengan foto sejarah pada umumnya, Dullaway mengubah foto sejarah monokrom menjadi berwarna. Ia mengubah foto sejarah monokrom "Uji Coba Nuklir oleh Militer Amerika Serikat di Pulau Bikini Kepulauan Marshall" pada tanggal 25 Juli 1946, foto Abraham Lincoln tahun 1863 koleksi Perpustakaan Kongres, dan foto Quang Duc, seorang biksu Budha yang melakukan aksi bakar diri di Saigon tanggal 11 Juni 1963 (Photograph: Malcom Brown) menjadi foto berwarna. Foto-foto tersebut kemudian menjadi viral di situs web reddit.com. Dullaway pernah memberikan keterangan bahwa foto Quang Duc monokrom adalah foto pertama yang memotivasinya melakukan pewarnaan foto sejarah 'to make the flames comes alive' (Henley, 2013).

Selain Sanna Dullaway, terdapat seniman digital lain yang mulai menjajaki seni mewarnai foto sejarah, seperti Jordan J Lloyd, Dana Keller, dan Paul Edwards. Seniman foto digital Lloyd mewarnai foto monokrom "Civil Right Movement: the March on Washington, 1963" atau gerakan hak sipil kulit hitam di Amerika, "American Civil War: Union Captain Cunningham, 1863" atau foto seorang Kapten pada Perang Sipil Amerika, dan "A Potrait from Dorothea Lange's Documentation of Great Depression" (Library of Congress), atau foto seorang anak perempuan yang melamun di kala krisis ekonomi tahun 1930 (Henley, 2013).

Dana Keller mewarnai foto sejarah monokrom sastrawan Mark Twain (foto diri) tahun 1907 (Photo: A.F.Bradley) dan Tragedi kecelakaan kapal hydrogen Hindenburg pada tanggal 6 Mei 1937 foto koleksi Everett (Corcoran, 2014). Bahkan Keller dalam situs web miliknya sendiri memiliki koleksi beberapa foto sejarah yang sudah diwarnai seperti tokoh bersejarah Adolf Hitler dan Jules Verne (1860). Selain itu Paul Edwards merupakan salah satu seniman foto digital yang dikenal atas pewarnaan foto sejarah terhadap foto nomokrom Albert Einstein yang terkenal memakai celana pendek, duduk di sebuah batu, di pinggir pantai Nassau Point, Long Island New York pada tahun 1939 (Corcoran, 2014). Para pelaku seni foto digital yang mewarnai foto sejarah semakin beragam seperti Mads Madsen, Andreas Larsson, dan Malakon (Huffpost, 2013).

Di Indonesia, tren pewarnaan foto sejarah digital dimulai oleh sebuah akun media sosial Twitter bernama @tukangpulas. Akun ini dioperasikan oleh seniman amatir bernama Heru Iswanto. Ia seorang anggota POLRI yang bertugas sebagai Staf Subdirektorat Keamanan dan Keselamatan Direktorat Lalu Lintas, Polda Metro Jaya. Wartawan dari Liputan6.com, Mochamad Wahyu Hidayat, sempat mewawancarai pemilik akun Twitter tersebut (Hidayat, 2017). Aktivitas @tukangpulas di Twitter sangat diminati oleh netizen (publik digital), ia memiliki 23.950 followers. 
Foto sejarah monokrom yang diwarnai adalah foto sejarah yang diabadikan oleh fotografer Schiedema "Persiapan baris-berbaris pasukan (Republik Indonesia) pasca perundingan Renville" di Bangil 8 Februari 1948, foto Muhammad Hatta bersama pengurus Indische Vereeniging atau Perhimpunan Indonesia tahun 1925, foto Serdadu Belanda yang dibebaskan setelah Jepang menyerah pada sekutu di Palembang tahun 1945, dan sebagai foto profil dari akun tersebut, ia memakai foto proklamasi (kemudian diwarnai) ketika Soekarno membacakan naskah Proklamasi tanggal 17 Agustus 1945 di Jakarta. Keempat foto tersebut hanya contoh dari 1.013 foto sejarah monokrom yang sudah diwarnai (Twitter, @tukangpulas).

\section{MEME FOTO SEJARAH}

Kebudayaan manusia dipengaruhi oleh perkembangan teknologi. Memasuki abad ke-21, meme tidak lagi diartikan sebagai ide yang berbentuk artefak fisik, namun artefak digital. Memasuki era internet, artefak kebudayaan manusia berkumpul dan tersebar di dunia maya atau dunia digital. Begitupun dengan meme (sebagai penyebaran ide) mengalami produksi besar-besaran ketika jarak komunikasi-yang diperpendek hingga sepersekian detik - semakin maju dengan kemunculan internet. Sejak saat itu, muncul sebuah perkembangan baru meme, yang disebut meme internet.

Istilah meme internet mengacu pada sebuah mimikri atau untuk tujuan humor semata dari pengguna (individu) ke pengguna lainnya melalui internet. Meme internet mengambil bentuk dari gambar dan teks. Perkembangan internet memiliki beberapa tahap. Pada tahap Ideology Web 1.0 hanya terdapat komunikasi satu arah antara penyedia konten dan pengguna internet, atau dengan kata lain antara penyedia informasi dan konsumen informasi. Pada perkembangan selanjutnya disebut Ideologi Web 2.0, yakni ketika sesama pengguna bisa saling berbagi informasi; mereka bisa menjadi produsen informasi sekaligus konsumennya. Contoh sederhananya adalah kemunculan media sosial, seperti Friendster, Facebook, Twitter, Instagram, Path, Whats Up, Line dan lainnya.

Melalui media sosial, setiap orang bisa berbagi banyak hal seperti tulisan (teks), foto, video, music, dan semua konten yang bisa disimpan secara digital. Meme internet semakin tersebar melalui media sosial tersebut. Setiap pengguna bisa berbagi humor, bahkan melewati batas-batas negara hingga Laut Atlantik. Pada tahap ini, meme internet lebih diakui sebagai imitasi yang mengandung parodi, sebab publik digital lebih mudah menyerap informasi humor daripada informasi yang terlalu serius.

Meme telah menjadi sebuah kebudayaan global yang mulai masuk ke dalam ingatan kolektif masyarakat Indonesia. Pada awalnya meme hanya bisa dibuat oleh para editor foto yang bisa menambahkan-garis, kata, warna-pada foto digital. Tentu, perubahan teknologi informasi menuju Ideologi Web 3.0 memungkinkan terjadinya timbal balik antara pengguna dan penyedia konten. Bahkan, mereka - para penyedia konten-menyediakan fitur khusus membuat meme, seperti Instameme, Memedroid, Memegene, Memegenerator, dan lainnya. Sedangkan para pengguna dapat menikmati nuansa humor yang terdapat pada meme tersebut.

Penggunaan istilah "meme foto sejarah" sejauh ini belum memiliki definisi yang utuh. Guna menunjukkan bahwa foto meme tersebut layak disandingkan dengan kata "sejarah" hanya melalui pertimbangan bahwa foto yang dipakai untuk membentuk 
sebuah foto meme berasal dari foto bersejarah. Pengertian foto sejarah dalam hal ini adalah foto yang dibuat di masa lalu, memiliki nilai sejarah, dan mewakili 'ingatan kolektif suatu masyarakat' tentang masa lalu mereka.

Sebagai contoh, akan ditampilkan beberapa meme foto sejarah digital yang muncul di dunia maya. Terdapat dua meme foto sejarah; meme Tan Malaka dan meme D.N. Aidit. Meme Tan Malaka dipasang oleh Dewan Kesepian Jakarta, sebuah situs web dan akun humor satir. Postingan ini dikutip ulang oleh media berita daring Merdeka.com pada tanggal 21 Desember 2014. Sebagai media satir, DKJ (Dewan Kesepian Jakarta) mengutamakan pesan "Jomblo" sebagai identitas yang intersubjektif.

Foto sejarah yang dipakai adalah sebuah foto paspor resmi Tan Malaka ketika berada di Singapura tahun 1926. Foto tersebut memuat separuh (passphoto) tubuh Tan Malaka yang di sampingnya terdapat cermin untuk menunjukkan dua sisi tubuh Tan Malaka (dari depan dan dari samping). Lalu pada foto meme sejarah tersebut ditambah (editing) dengan kata-kata Tan Malaka yang terkenal, yang dikatakannya saat berpidato di hadapan Lenin pada pertemuan Komunis Internasional (Komintern) pada tahun 1922. Teks tersebut bertuliskan "Di Hadapan tuhan, aku seorang Muslim; di hadapan manusia aku seorang komunis; di hadapan Mantan ... aku hanya butiran debu". Teks tersebut sudah diubah dari aslinya, sebab teks asli berbunyi "Di Hadapan tuhan, aku seorang Muslim; di hadapan manusia aku seorang komunis". Pembuat meme tersebut menambahkan "di hadapan Mantan...aku hanya butiran debu." Foto ini dianggap meme karena mengandung nuansa humor.

Tan Malaka adalah tokoh pejuang Nasional. Kata-kata dan tulisan-tulisannya telah menjadi inspirasi berbagai gerakan sosial-politik di Indonesia. Namun melalui meme tersebut, kata-kata Tan Malaka yang memiliki semangat juang pada zamannya berubah menjadi sekedar ironi hubungan percintaan. Padahal teks tersebut memuat pernyataan yang paling tidak mungkin dibicarakan selama pemerintahan Orde Baru, yakni kalimat pengakuan "di hadapan manusia aku seorang komunis", sebab kata PKI atau Komunis sangat terlarang dibicarakan secara publik di Indonesia selama 32 tahun rezim Soeharto. Pembuat meme Tan Malaka tersebut juga tidak secara arbitrer mengaitkan antara Tan Malaka, pernyataan deklaratifnya, dan "mantan" sebagai tema menarik bagi para millennials. Faktanya, Tan Malaka tidak pernah secara resmi memiliki pendamping hidup sepanjang hayatnya. Teks tersebut juga memiliki tiga pernyataan deklaratif. Pertama, di hadapan Tuhan sebagai Muslim, di hadapan manusia sebagai komunis, dan di hadapan mantan hanyalah butiran debu.

Kata butiran debu bagian dari kreasi pembuat meme yang mengutip sebuah lirik lagu yang ditulis Chakra Khan (musisi pop yang baru saja terkenal). Lagu tersebut merupakan lagu populer di tahun 2014. Artinya, meme dengan foto sejarah memuat beberapa pesan sekaligus. Pertama, mengingatkan pernyataan deklaratif Tan Malaka, mengaitkan Tan Malaka dengan masa kini, dan mengubah nuansa serius ideologis dalam kata-katanya menjadi kata-kata yang penuh humor ironi. Sebab kata mantan merupakan istilah yang menunjukkan seseorang yang pernah dicintai atau dijalin kasih dengannya, namun masih begitu sulit melupakannya. Teks akhirnya mampu menjangkau penerima pesan konotatif. Fenomena perasaan ini berlaku bagi banyak kalangan kids zaman now, sehingga menggunakan istilah mantan bisa mengaitkan 
masa lalu pada ingatan kolektif masyarakat kekinian pengguna kata tersebut menjadi semacam ironi yang perlu ditertawakan.

Foto selanjutnya adalah Meme D.N. Aidit. Ia adalah tokoh sejarah penting dalam perjuangan kemerdekaan Indonesia hingga peristiwa 1965. Ia adalah ketua Umum Partai Komunis Indonesia (PKI). Foto sejarah digital Aidit yang dibuat meme adalah foto Aidit yang sedang berpidato di sebuah mimbar yang memiliki lambang palu arit beserta tulisan PKI. Foto tersebut diambil dari surat kabar Harian Rakjat tahun 1955. Ketika diubah menjadi meme, ditambahkan teks "Kalau Sedjarah PKI kau sebut kelam (enter) lalu kisah cintamu itu kau sebut apa?!". Keseluruhan teks yang dicantelkan pada gambar tidak memiliki catatan historis sezaman dengan foto tersebut.

Bagi ingatan kolektif di Indonesia pasca 1965 secara umum, "Palu arit", "PKI", dan "Aidit" merupakan padanan kata terlarang yang tabu untuk dibicarakan secara normatif. Akibat dari doktrinisasi negara melalui pemutaran film Penumpasan Penghianatan G30S/PKI setiap tahun sejak tahun 1984, segala yang berhubungan dengan "Palu Arit", "PKI", "Aidit dan Komunis" merupakan hal terlarang. Foto meme Aidit tersebut ditambahkan kalimat reflektif "kalau Sedjarah PKI kau sebut kelam, lalu kisah cintamu kau sebut apa?" teks ini disebut pesan parasit. Pertama, menguji sejauh mana kata kelam berarti bagi masyarakat Indonesia masa kini. Kedua, membandingkan dengan keresahan umum yang dialami generasi milenial, yang pada umumnya memiliki kisah cinta yang kelam. Hal ini berupa penolakan, penghianatan, dan situasi percintaan menyedihkan lainnya. Artinya, teks mengarahkan imaji (foto Aidit). Hubungan antara teks dan foto disebut Barthes sebagai "pencatelan teks". Ia menyebutkan:

"Pertama, teks merupakan pesan parasit yang didesain untuk mengkonotasikan imaji, atau melapisi imaji dengan petanda kedua. Dengan kata lain, dan ini merupakan titik balik historis yang penting, pencatelan kata-kata ini membuat imaji tidak lagi 'mengilustrasikan' kata-kata sebagai sesuatu yang jauh di luar dirinya. Titik balik historis ini menuntut korban: pada ilustrasi-ilustrasi tradisional, imaji berfungsi sebagai pengurai atau penerjemah teks (pesan dasar) yang bersifat konotatif (tersembunyi) menjadi denotatif (terungkap). Sementara, ketika kata-kata tertulis secara langsung pada imaji, imaji tidak lagi menguraikan atau 'menampakkan' teks, tetapi teks yang mensublimasi atau merasionalisasi imaji (Barthes, 2010:12)."

Dalam konteks cinta melankolis, teks ini mengajak para pengguna digital untuk melihat kembali, apa betul Sedjarah PKI "kelam"?. Lalu segera mengaitkannya dengan kondisi aktual bagaimana dengan kisah cintamu sendiri?. Melalui meme, nuansa serius dalam foto tersebut, yang sering dipakai untuk menggambarkan propaganda PKI oleh pihak lawannya menjadi hilang. Sebab, foto Aidit sudah tersublimasi teks, diganti dengan nuansa otokritik, sehingga mengungkap ironi yang hidup dalam setiap individu. Ironi ini baru menjadi humor ketika foto Aidit menjadi latar teks. Tanpa gambar Aidit yang berpidato berapi-api dan foto itu diingat sebagai "propaganda politik jahat" - eskalasi keseriusan yang sakral menukik jatuh pada persoalan profan. Bahwa melalui masa lalu yang dianggap kelam, teks dan foto tersebut mempertanyakan "kekelaman" yang terjadi di masa kini pada setiap viewers meme. Maka munculah parodi dan ironi. 


\section{RISIKO FILOSOFIS DAN METODOLOGIS}

Di era milenials, foto sejarah yang diwarnai dan yang dijadikan meme merupakan artefak digital. Pada umumnya, kedua fenomena ini dianggap tidak memiliki peranan penting dalam pengembangan dan perluasan sumber-sumber sejarah. Alasan utama pendapat tersebut karena kurangnya pengetahuan para pengkaji sejarah tentang artefak digital (beserta forensik digital), sehingga kurang dipercayai untuk dapat digunakan sebagai sumber sejarah. Kemudian muncul daya tolak untuk tidak menggunakannya. Upaya untuk mendekati artefak digital (foto digital) sebagai sumber sejarah sebenarnya merupakan upaya yang umum dilakukan oleh kalangan sejarawan. Pentingnya mendekati fakta sejarah menurut E.H. Caar adalah "to praise a historian for this accuracy is like praising an architect for using Wellseasoned timber or properly mixed concrete in his building. It is a necessary condition of his work, but not his essential function" (Carr, 1982).

Di sisi lain, Roland Barthes memang tidak menjanjikan bahwa pesan fotografis dapat menunjukkan kebenaran yang utuh tentang pesan yang terdapat dalam foto. Namun, sangat mungkin kajian pesan fotografis meningkatkan akurasi fakta dalam menggali ingatan masa lalu pada foto. Seperti pendapat E.H. Carr, sejarawan memang dituntut dan perlu mendekati fakta sejarah. Namun itu bukanlah fungsi esensialnya. Secara pesimis, E.H. Carr menyebut:

"if the historian necessary look at his period of history through the eyes of his own time, and studies the problems of the past as a key to those of the present, will he not fall into a purely pragmatic view of the facts, and maintain that the criterion of a right interpretation is its suitability to some present purpose? On this hypothesis, the fact of history are nothing, interpretation is everything. Nietzsche had already enunciated the principle: 'the falseness of an opinion is not for us any objection to it... the question is to how far it is life-furthering, life-preserving, special-preserving, perhaps specialcreating" (Carr, 1982).

Pernyataan bahwa sejarah-sebagaimana ilmu-ilmu lain-hanyalah interpretasi tidak harus dibantah. Sebab sejarawan memang tidak didorong untuk mencapai hal-hal demikian. Sejarah secara objektif tidak bisa dicapai sebagaimana impian untuk berkunjung ke masa lalu melalui mesin waktu. Perkembangan teknologi memungkinkan hal tersebut, namun dengan cara-cara sekunder. Salah-satunya adalah keberhasilan foto dalam menggambarkan realitas. Meski fakta sejarah tidak selalu hadir dalam keadaan utuh dalam interpretasi foto, namun masih dimungkinkan bahwa melalui foto, sejarawan memiliki akses untuk mengunjungi fakta sejarah. Selain itu, fakta sejarah menjadi mati dan tak bermakna tanpa sejarawan. E.H. Caar mengatakan "the historian without his facts is rootless and futile; the fact without their historian are dead and meaningless.." Lalu apa itu sejarah? Carr menambahkan "is that it is a continuos process of interaction between the historian and his fact, an unending dialogue between the present and the past" (Carr, 1982).

Sejarawan memiliki pekerjaan tradisional untuk mengunjungi fakta sejarah. Namun, dalam proses tersebut-melalui perkembangan teknologi digital-relasi antara masa lalu dan masa kini mulai dikuasai oleh para seniman digital. Seniman foto digital yang melakukan "pewarnaan foto sejarah" berbekal kemampuan untuk 
mengubah foto digital, dapat menghadirkan masa lalu sedekat mungkin dengan cara mewarnai foto sejarah. Di sisi lain, orisinalitas yang menjadi poin penting dalam metodologi sejarah selalu mengarahkan fakta sejarah pada kebenaran sejarah. Kekhawatiran bahwa seniman foto digital melakukan "kreasi imajinasi" dalam pemilihan warna foto sejarah yang sudah diwarnai, tanpa proses verifikasi dan perbandingan data sezaman, cukup beralasan dari sisi metodologi sejarah.

Kekhawatiran tersebut pernah dikemukakan oleh Jon Henley, seorang koresponden The Guardian dan Jurnalis asal Perancis. Dua pertanyaannya sangat menarik: apakah pewarnaan foto sejarah merupakan bentuk seni baru atau malah penodaan? Dan menghidupkan masa lalu atau mengubah sejarah? (Henley, 2013). Pertanyaan tersebut hendak dijawab oleh Matt Novak dalam artikelnya Are Colorized Photos Rewriting History?. Ia berupaya menguji keabsahan dan orisinalitas foto sejarah yang diwarnai. Ia pernah mengkritik sebuah akun media sosial History In Pic. yang memajang foto sejarah yang sudah diwarnai, yaitu foto Golden Gate Bridge in 1940 tanpa menyertai keterangan bahwa foto monokrom tersebut telah melalui proses pewarnaan.

Selain itu, Lloyd-seniman foto digital-pernah di-wawancara mengenai akurasi dari pewarnaan foto sejarah "Steve Jobs" pada tahun 1985 yang difoto oleh fotografer Norman Seeff. Pada foto tersebut, Lloyd mewarnai sweeter Steve Jobs dengan warna merah, namun ia tidak melakukan penyelidikan apakah sweeter tersebut benar-benar berwarna seperti itu. Lloyd mengatakan "WTF, I didn't even realize i was on or Colorized History. Completely undetectable coloring." Bukan hanya Lloyd, Paul Edwards yang mewarnai foto sejarah "Depicts Ballet Dancer in 1924" tidak mengetahui warna asli foto tersebut di zamannya. Novak kemudian menyimpulkan, apabila pewarnaan foto sejarah mengingatkan kita tentang sejarah adalah satu sisi. Di sisi lain, hal tersebut merupakan ingatan yang salah (Novak, 2014).

Majalah daring Gizmodo juga mewawancarai Dana Keller, seniman foto digital. Pada pertanyaan bagaimanakah pewarnaan foto sejarah mempengaruhi pemahaman tentang sejarah, ia menjawab bahwa penambahan warna bisa "menghubungkan" orang dengan sejarah. Ia melanjutkan, "it can bridge the gap from a seemingly distant event and make it more immediate and relevan. We can also build on any existing knowledge of color in the image to create a more accurate representation of history" (Gizmodo.com, 22 Mei 2014).

Ketika foto sejarah berada di tangan sejarawan, hal tersebut akan menjadi sesuatu yang sangat penting bagi ingatan kolektif. Sedangkan ketika foto sejarah di tangan seniman foto digital, "prinsip kebenaran" dalam sejarah ditinggalkan demi pesan "artistik". Hal ini sudah diuraikan oleh Barthes sebagai tahap kedua konotasi, yaitu fotogenia. Tahap ini disebut elemen-elemen estetis (Aesthetic effect). Di sisi lain, meme foto sejarah hanya "menculik" foto sejarah sebagai latar dan sepenuhnya menjadi sejarah milik zaman sekarang. Pada meme foto sejarah, nilai sejarah tidak hilang, hanya saja perspektif zaman digital hampir mengambil secara menyeluruh makna pada imaji melalui teks yang dicantelkan. Pewarnaan foto sejarah dan meme foto sejarah memang memiliki risiko memanipulasi artefak digital, tanpa menghilangkan fakta sejarah yang terdapat pada foto, namun malah menghadirkan fakta sejarah baru dalam foto sejarah yang sama. 
Kondisi tersebut menghadirkan pesimisme baru, apakah "pewarnaan foto sejarah dan meme foto sejarah" dapat mencapai kebenaran sejarah? Ketidakmampuan seniman digital yang mewarnai foto sejarah maupun pembuat meme foto sejarah untuk mencapai kebenaran sejarah, sesungguhnya merupakan ruang yang tersedia bagi sejarawan untuk tetap hadir, memperingati, dan memberi kritik atas kekurangan mereka. Kondisi ini tidak mengharuskan para seniman pewarnaan foto sejarah dituduh sebagai pemalsu foto sejarah dan menyebut pembuat meme foto sejarah sebagai "pembuat lelucon buruk".

Sanna Dullaway sebagaimana seniman foto digital membuat keputusan bijak dengan cara menampilkan keduanya; foto sejarah monokrom beserta keterangan historis-nya dengan foto yang sudah diwarnai olehnya. Hal ini menunjukkan seniman digital sudah membatasi dirinya untuk tetap menampilkan foto sejarah di satu sisi, dan kreasi seniman digital sisi lain. DKJ yang membuat meme foto sejarah tetaplah menggunakan teks sejarah untuk memperkuat meme mereka (meme foto Tan Malaka). Artinya mereka tetap berupaya memakai referensi teks sejarah bagi humor mereka. Terlepas apakah hal tersebut keliru, karena beberapa penambahan dan manipulatif, adalah tugas sejarawan untuk menjelaskan kedudukan para kreator seniman digital (para pewarna dan pembuat meme foto sejarah) di hadapan sejarah, di hadapan artefak digital, dan kebenaran sejarah.

Fenomena selanjutnya selalu berlawanan dengan perkembangan yang dianggap menuju kemajuan linear. Dalam sebuah konferensi Desain Internasional yang diadakan pada tanggal 17-20 Mei 2010 di Dubrovnik Kroasia, N. Volaric, J. Pibernic dan J Dolic menunjukkan sebuah hasil penelitian mengapa foto monokrom tetap populer meski dunia fotografi sudah mengenal foto berwarna. Penelitian tersebut menyatakan bahwa beberapa responden menyatakan pesona foto monokrom dianggap menunjukkan dunia yang berbeda dari mata yang bisa melihat banyak warna (Volarić, Pibernik, \& Dolić, 2010).

Fenomena pewarnaan foto sejarah dan meme foto sejarah merupakan hubungan timbal-balik antara masa lalu dan masa kini. Melalui pesan fotografis Roland Barthes, bisa diuraikan lebih rinci bagaimana realitas dalam foto bekerja dan mempengaruhi interpretasi terhadap sumber sejarah. Pada tahap demikian, disebut sebagai kesadaran historikal (Historische Bewusstein), yakni bahwa tiada penglihatan (visual) dan pemahaman yang murni terhadap sejarah tanpa kaitan dengan masa kini. Namun juga, tidak berarti bahwa makna bagi kita sekarang secara mutlak berbeda dari makna bagi orang zaman dulu itu... Masa lalu bukan hal yang asing bagi masa kini (Poespoprodjo, 1987).

\section{KESIMPULAN}

Fenomena pewarnaan foto sejarah (termasuk mengubahnya menjadi monokrom) dan meme foto sejarah menunjukkan beberapa aspek yang mempengaruhi: perubahan teknologi, kesadaran zaman, dan manusia itu sendiri. Pada aspek pertama, perkembangan teknologi fotografi dari ditemukannya prinsip lensa oleh Ibn Al-Haytham, penemuan kamera abad ke-19, hingga diciptakannya foto yang mengalahkan lukisan realis manapun. Kemudian, perkembangan komputasi 
yang mempengaruhi cara kerja kamera analog menjadi kamera digital memperluas medium foto berada dalam dunia digital.

Pada aspek kedua, kesadaran zaman milenium yang diartikan sebagai era millennials, membuat banyak kalangan di luar sejarawan memiliki akses terhadap sumber sejarah. Foto sejarah yang bisa diakses di dunia digital (internet) membuat mereka melakukan kreasi, seperti mengubah tekstur, warna dan garis, bahkan menambahkan teks. Pada meme foto sejarah, para pembuat meme melakukan kreasi terhadap foto sejarah untuk mengambil nuansa humor, bahkan dari sebuah foto yang dianggap sakral sekalipun. Hal ini merupakan negasi anti-thesis dalam konsep dialektika bahwa sejarah manusia "bergerak" melalui penyangkalan-penyangkalan.

Pada aspek terakhir adalah manusia. Perubahan teknologi menyebabkan manusia mampu mendekati sejarah. Mengubah foto monokrom menjadi berwarna seakan-akan sejarah terjadi baru saja kemarin. Namun di sisi lain, fotografi monokrom tetap diminati, bahkan di media sosial. Hal ini menunjukkan sekalipun manusia berharap bisa mendekati masa lalu dengan perangkat teknologi yang dimilikinya, mereka tetap menjadikan sejarah berada pada jarak tertentu sehingga tetap bernilai. Pewarnaan foto sejarah, munculnya meme foto sejarah, hingga keadaan berbalik foto berwarna yang justru dibuat menjadi monokrom hanya menunjukkan satu hal: betapa berharganya bagi manusia untuk memiliki akses terhadap masa lalu.

\section{DAFTAR PUSTAKA}

Ali, H., \& Purwandi, L. (2016). Indonesia 2020. Jakarta: Alvara Research.

Ali, H., \& Purwandi, L. (2017). The Urban Middle-Class Millenials Indonesia. Jakarta: Alvara Research.

Angkersmith. (1987). Refleksi Tentang Sejarah. (D. Hartono, Trans.) Jakarta: Gramedia Pustaka Utama.

Barksdale, K. (2012). Digitools (3nd ed.). Mason USA: Cengage Learning.

Barthes, R. (2007). Petualangan Semiologi. (M. Ardiansyah, Trans.) Yogyakarta: Pustaka Pelajar.

Barthes, R. (2010). Imaji, Musik, Teks. (A. Hartono, Trans.) Yogyakarta: Jalasutra.

Blackmore, S. (2000). The Power of Memes: Behaviors and Ideas Copied from Person to Person by Imitation-Memes-May Have Forced Human Genes to Make Us What We are Today. 65-73.

Carr, E. H. (1982). What is History? London: Pinguin Books.

Corcoran, K. (2014, August 9). DMG Media. (G. Greig, Editor) Retrieved October 10, 2017, from Dailymail.com: https://www.dailymail.co.uk/news/article2719183/Audrey-Einstein-Red-Baron-crashing-Hindenburg-colour-Howmodern-computer-techniques-brought-new-life-black-white-images-earlydays-photography.html

Dawkins, R. (2018). The Selfish Gene (3nd ed.). (K. El-Kazhiem, Trans.) Jakarta: Kepustakaan Populer Gramedia. 
Dobson, M. \&. (2009). Reading Primary Sources: The Interpretation of Text from Nineteeth- and Twentieth-Century History. New York: Routledge.

eMarketer. (2015, September 16). Article eMarketer. Retrieved November 12, 2017, from eMarleter: https:/www.emarketer.com/Article/Asia-Pacific-Boasts-MoreThan-1-Billion-Smartphone-Users/1012984

Gottschalk, L. (1986). Mengerti Sejarah. (N. Notosusanto, Trans.) Jakarta: UI Press. Harrison, D. (2015). Handbook of Research on Digital Media and Creative Technologies. Hershey: IGI Global.

Henley, J. (2013, November 18). (P. Chadwick, Editor) Retrieved November 11, 2017, from Theguardian.com: https://www.theguardian.com/artanddesign/2013/nov/18/vivid-art-ofcolorizer

Heriyanto, A. P. (2016). Mobile Phone Forensics: Theory Mobile Phone Forensics and Security Series. Yogyakarta: CV ANDI.

Hidayat, M. W. (2017, March 30). PT Liputan Enam Dot Com. Retrieved October 28, 2017, from liputan6.com:

https://www.liputan6.com/tekno/read/2901080/sosok-polisi-di-balik-akuntwitter-pewarna-foto-foto-sejarah

Horovitz, B. (2012, May 4). USA TODAY . (N. Carrol, Ed.) Retrieved November 4, 2017, from Usatoday.com:

http:/usatoday30.usatoday.com/money/advertising/story/2012-05-03/namingthe-next-generation/54737518/1 ?loc=interstitialskip

Howe, N., \& Strauss, W. (2000). Millennials Rissing. New York: Vintage Books.

Huffpost. (2013, November 9). The Huffington Media Group. (T. Craggs, Editor)

Retrieved October 2, 2017, from Thehuffingtonpost.com:

https://www.huffingtonpost.com/2013/11/09/colorizedphotos_n_4242066.html

Iskandar, A. A. (2014, September- December 3-4). Pengantar Ketua Himpunan Optik Indonesia. Buletin HOI, III, p. 25.

Kuntowijoyo. (2001). Pengantar Ilmu Sejarah. Yogyakarta: Yayasan bentang Budaya.

Matanasi, P. (2016, October 31). Perpustakaan Leiden, Jendela Indonesia Di Belanda.

Retrieved October 20, 2017, from Tirto.id: https://tirto.id/perpustakaan-leidenjendela-indonesia-di-belanda-bZnX

Mitchell, W. J. (1998). The Reconfigured Eye. Cambridge: MIT Press.

Mitchell, W. J. (1998). The Reconfigured Eye: Visual Truth in The Post-Photographic Era. Cambridge: MIT Press.

National Institute of Justice. (2008). Electronic Crime Scene Investigation. National Institute of Justice, U.S Department of Justice. Washington: National Institute of Justice. 
Nordholt, H. S., \& dkk. (2008). Perspektif Baru Penulisan Sejarah Indonesia. Jakarta: Yayasan Obor.

Novak, M. (2014, May 21). Gizmodo Media Group. (K. Bourdet, Editor) Retrieved October 23, 2017, from Gizmodo.com: https://paleofuture.gizmodo.com/arecolorized-photos-rewriting-history-1579276696

Novak, M. (2014, May 22). Gizmodo Media Group. (K. Bourdet, Editor) Retrieved November 11, 2017, from Gizmodo.com:

https://paleofuture.gizmodo.com/inside-the-color-factory-my-chat-with-aphoto-colorize-1579297729

Peres, M. R. (2012). The Concise Focal Encyclopedia of Photography (2nd ed.). Burlington: Focal Press.

Poespoprodjo, W. (1987). Interpretasi. Bandung: Redmaja Karya.

Rotenberg, J. (2000). An Experiment in Using Emulation to Preserve Digital Publications. Amsterdam: NEDLIB.

Volarić, N., Pibernik, J., \& Dolić, J. (2010). The Popularity Of Black-And-White Photography In The World Of Digital Photography. University of Zabreg. Zabreg: International Design Conference - Design 2010.

Yulistianti, A. (2008). Bekerja sebagai Desainer Grafis. Jakarta: Erlangga. 